Biochem. Lett., Vol.4, PP 55-68 (2008)

\title{
STUDIES ON THE EFFECT OF ULTRASONIC WAVES ON: SUGAR METABOLISM AND SOME ACTIVITIES OF HYDROLYTIC ENZYMES OF ARACHIS HYPOGAEA SEEDLINGS AND CULTURED TISSUES
}

\author{
By \\ Hegazy, H.S. ; Ghazi, S.M.* and Daif, H.E. \\ Department of Botany, Faculty of Science, Zagazig University \\ *Department of Botany, Faculty of Science, Helwan University
}

\begin{abstract}
The variation of sugar metabolism and related enzymes of peanut seedlings and cultured tissues by ultrasonic waves were carried out in this work. It was found that reducing sugars and sucrose contents of peanut seedlings are more sensitive to ultrasonication than polysaccharides and total carbohydrate contents. The reduction decrease in direct reducing sugars, sucrose and total carbohydrate contents were proportional with increasing time of exposure.

The present data obtained showed that amylase activity of peanut seedlings and cultured cells were increased with ultrasonication, while invertase activity decreased.

\section{INTRODUCTION}

There has been an increasing interest in the applications of ultrasonic waves in our modern life. Since last decade, lots of efforts in development and construction of ultrasonic equipment for medical diagnosis had been made. So far, knowing ultrasonics, as physical agent such as $\mathrm{X}$-rays and gamma rays to induce variations in plants was scantly to improve crops. However, there was very little information available in its use in biological studies ${ }^{(1)}$.
\end{abstract}




\section{STUDIES ON THE EFFECT OF ULTRASONIC WAVES ON:}

The generation of ultrasonic vibration may be mechanical, thermal, piezoelectric and magnetostrictive ${ }^{(2)}$.

An extensive efforts hade applied sonication under dry conditions which may be carried out up to several months before actual sowing. Examples of the use of this process include ultrasonic treatment leading to a three fold enhancement in sunflower seed germination in soil and a ten-day reduction in the ripening time of tomatoes or shorter period to form a gel as a result in a faster release of starch during subsequent cooking in a sonicated rice grain in water ${ }^{(3)}$.

In biotechnological processes, ultrasonication method was widely used for laboratory scale and it did not require sophisticated equipment or extensive technical training. The structure and function of biological molecules can be changed by the ultrasound irradication. The most common interaction mechanisms which involved in this case were either heat or chemical effects and acoustically induced cavitational activity. In addition to these, acceleration the rate of influx or uptaking of a substance into a seed by ultrasonication could also be caused by mechanical effects ${ }^{(2)}$.

The mechanical effects of ultrasonic waves that caused rupture of tissue and fragmentation of cells came from three sources: (1) Cavitation, (2) Stress gradients in a sound wavelength, and (3) The bombardment of some structural element by particles that had been given a high acceleration by the sound waves.

Ultrasonic waves had been long recognized as a germination inhibitor ${ }^{(4)}$. Also ${ }^{(5)}$ observed that the ultrasonication had much effect in reducing the germination of Vigna sinensis L. and percentage of germination decreased gradually with increasing time of exposure.

Short exposure to ultrasonic waves showed a slight increase in the germination percentage of Dolichos biflorus L. seeds, however an increased time of exposure caused a gradual decline in the percentage of germination. Thus may be attributed to the stimulative or inhibitive action of ultrasonic waves on activity of some enzymes ${ }^{(6)}$. 
Hegazy, H.S. et al.

Photosynthetic products of ultrasonic waves plants were declined due to decrease of chlorophyll content, ${ }^{(5)}$ reported that inhibition in total chlorophyll synthesis in Vigna sinensis was caused with long exposure to ultrasonic waves.

$\mathbf{R a o}^{(7)}$ found that ultrasonication effect was more pronounced on the structure and pigmentation of the chloroplast of the treated plants.

Reddy $^{(8)}$ showed that amylase activity in different parts of Vigna radiata seedlings was directly correlated with time of exposure to ultrasonic waves. They also added that long exposure to ultrasonic waves given to Vigna radiata had presently unfavoured.

The present work is a spot light on the effect of ultrasonication on the sugar metabolism as well as related enzymes of peanut seedlings and cultured cells.

\section{MATERIAL AND METHODS}

\section{(I) Seed germination and ultrasonication:}

Peanut (Arachis hypogaea linn, cultivar Giza 4) was used as experimental plant during this work. Pure strains of seeds were supplied from Egyptian Agriculture Research Center, Giza. Seeds were pre-soaked in distilled water for 13 hours, then germinated until radicle length become $2-3 \mathrm{~cm}$. Ultrasonication was carried out using ultrasonic apparatus Bkansonic, Mod. B-5200.Hf-out put power = $120 \mathrm{w}$, working frequency $=47 . \mathrm{kHz} \pm 6 \%$ for 15 and 60 minutes, at a time 200 seeds taken in $500 \mathrm{ml}$ of distilled water. The level of the water was kept uniform during exposure. Control seedlings were kept without ultrasonication. Sugar metabolism and some activities of hydrolytic enzymes (amylase and invertase) were investigated in treated and untreated seedlings after 3, 24, 48 and 72 hours of exposure.

\section{(II) Cell suspension culture and ultrasonication:}

\section{(A) Initiation of peanut callus:}

Calli tissues were grown on MS medium ${ }^{(9)}$ solidified by addition of $12 \mathrm{~g}$ agar/L. Explants $5 \mathrm{~mm}$ hypocotyl sections obtained from 5 daysold seedlings grown axenically in the dark at $28^{\circ} \mathrm{C}$. Explants were placed on MS semisolid medium in sterile Petri dishes and after 4 weeks, proliferating undifferentiated tissues were isolated and 


\section{STUDIES ON THE EFFECT OF ULTRASONIC WAVES ON:}

transferred to fresh MS medium. Subsequent subculture was done for several times. MS medium was supplemented with $0.4 \mathrm{mg} / \mathrm{L}$ NAA (naphthaline acetic acid)/L and $2.0 \mathrm{mg} / \mathrm{L}$ Kinetin for initiation and then with $4 \mathrm{mg} / \mathrm{L}$ NAA and $0.4 \mathrm{mg} / \mathrm{L}$ Kinetin for subculturing, adjusted to $\mathrm{pH} 5.8$ and all cultures were incubated at $28^{\circ} \mathrm{C}$ and kept in $\operatorname{dark}^{(10)}$.

\section{(B) Cell suspension culture preparation:}

For preparation of cell suspension cultures, $0.3 \mathrm{~g}$ fresh weight of actively growing callus tissue were transferred to MS liquid media and were incubated on a horizontal shaker at $100 \mathrm{rpm}$.

\section{(C) Exposure of cultured cells to ultrasonication:}

$100 \mathrm{ml}$ of cell suspension culture of peanut in Erlen-mayer flasks was taken and exposed to ultrasonic waves in water medium for 30 minutes. Cell suspension culture of peanut was kept without ultrasonication and used as control. Both treated and untreated cell suspension cultures were left on shaker for 24 hours. Cells were then harvested and used for certain metabolism and estimation of some activities of hydrolytic enzymes (amylase and invertase).

\section{(1) Determination of carbohydrates:}

The method of extraction adopted in this investigation was that of ${ }^{(11)}$ Younis (1963).

\section{(A)Estimation of direct reducing value (D.R.V):}

Estimation was carried out according to the method of ${ }^{(12)}$, and modified by ${ }^{(13)}$. Standard curve was constructed using different concentrations of glucose.

(B) Estimation of total reducing value (T.R.V.):

A known volume of the extract was mixed with $2 \mathrm{mls}$ of invertase $(5 \%)$ then incubated in water bath at $35^{\circ} \mathrm{C}$ for 6 hours. The reducing value was determined as mentioned above.

(C) Estimation of polysaccharides:

After extraction of soluble carbohydrates, the residue was dried down at $80^{\circ} \mathrm{C}$ till constant weight for determination of 
polysaccharides as adopted by ${ }^{(14)}$. A known weight (1 gm) was hydrolysed in sulphuric acid $(1.5 \mathrm{~N})$ at $100^{\circ} \mathrm{C}$ for 6 hours using a reflux condenser. The reducing value was estimated as described before.

\section{(2) Assay of enzymes:}

\section{(A) Amylase:}

\section{(i) Extraction of crude enzyme:}

A known weight (1 gm) of fresh plant material and cultured cells of peanut were ground using phosphate buffer ( $\mathrm{pH}$ 7.4). Centrifuged at $3000 \mathrm{rpm}$ for 20 minutes. The precipitate was washed and centrifugated, then supernatant was transferred to dialysis bag. Dialysis was carried out using concentrated solution of sucrose at $4{ }^{\circ} \mathrm{C}$ for 24 hours until very small volume. Dialysate was completed to a known volume and kept in a deep freeze till required.

\section{(ii) Quantitative determination of amylolytic activities:}

According to the method described by ${ }^{(15)}$, sample of $0.1 \mathrm{ml}$ (crude enzyme extract) was added to $1 \mathrm{ml}$ of $2 \%$ starch and $1 \mathrm{ml}$ of phosphate buffer ( $\mathrm{pH}$ 7.4) in test tube. Blank was made in the same way but instead of crude enzyme extract, $0.1 \mathrm{ml}$ of distilled water was used. Both sample and blank were incubated at $37^{\circ} \mathrm{C}$ for one hour. Boiling to stop the reaction of enzyme then completed to a known volume (5 $\mathrm{ml}$ ). According to the method described by ${ }^{(12)}$, the produced reducing sugars were determined using glucose as standard.

\section{(B) Invertase:}

\section{(i) Extraction of crude enzyme:}

According to ${ }^{(16)}$ method, a known fresh weight $(1 \mathrm{gm})$ of plant material and cultured cells of peanut were ground using $0.5 \mathrm{M} \mathrm{NaCl}$, then centrifuged at $3000 \mathrm{rpm}$ for 20 minutes. Ammonium sulfate $(75 \%)$ was added to precipitate protein, and then was left at $4^{\circ} \mathrm{C}$ for 24 hours, centrifuged at 20,000 rpm, the precipitate was collected and dissolved in $1 \mathrm{ml}$ of $0.15 \mathrm{M} \mathrm{NaCl}$.

\section{(ii) Quantitative determination of invertase activities:}

The mixture consists of $0.1 \mathrm{ml}$ crude extract, $0.2 \mathrm{ml}$ of $0.1 \mathrm{M}$ sodium acetate $(\mathrm{pH} 5.0), 0.1 \mathrm{ml}$ of $0.15 \mathrm{M} \mathrm{NaCl}$ and $0.1 \mathrm{ml}$ of $0.73 \mathrm{M}$ sucrose. A blank for each sample was prepared as before. Both of the 


\section{STUDIES ON THE EFFECT OF ULTRASONIC WAVES ON:}

samples and blanks were incubated at $37^{\circ} \mathrm{C}$ for one hour, and then boiled to stop the reaction. According to ${ }^{(12)}$, the amount of reducing sugars was determined using glucose as standard.

\section{RESULTS}

\section{(1) Effect of ultrasonication on sugar metabolism of Arachis hypogaea seedlings:}

Direct reducing value (D.R.V) was represented in Fig. (1a) which revealed that ultrasonication significantly decreased the reducing sugars in peanut seedlings as compared with untreated seedlings. Short exposure to ultrasonic waves (15 minutes) gradually increased the content of reducing sugars in treated seedlings ( 3 up to 72 hours) after exposure, while long exposure (60 minutes) increased its content of reducing sugars ( 3 hours) after exposure as compared with untreated seedlings.

Results in Fig. (1b) showed that, the level of sucrose was decreased by ultrasonication in both of short and long exposure. Moreover, the sucrose content decreased by increasing the age of seedlings (3-72 hours) in both treated and untreated seedlings. Also the results showed that short exposure was more effective on sucrose content (highly significant) of treated seedlings than long exposure.

Results in Fig. (1c \& d) revealed that, polysaccharides and total carbohydrates were decreased with lapse of time of germination (3 up to 72 hours) in treated and untreated seedlings. Moreover, the reduction was highly significant $(\mathrm{P}<0.001)$ in both polysaccharides and total sugars at 3,24 and 72 hours after long exposure to ultrasonic waves.

(2) Effect of ultrasonication on the activity of both amylase and invertase enzymes of Arachis hypogaea seedlings and cultured cells:

Fig (2) showed that, the relative increase in amylase activity of treated and untreated peanut seedlings. Long exposure to ultrasonic waves (60 minutes) has increased the amylase activity as compared with untreated seedlings after 24 hours. Short exposure (15 minutes) 
Hegazy, H.S. et al.

reduced the amylase activity than long exposure (60 minutes) except at 72 hours after exposure in which there was a marked increase in the amylase activity as compared with untreated seedlings. Table (1) shows that, ultrasonication decreased the activity of amylase in exposed cultured cells than unexposed ones.

Fig. (3) showed that the ultrasonication in the short and long exposure led to a relative decrease in the invertase activity as compared with untreated seedlings. Table (1) showed that ultrasonication decreased the activity of invertase in exposed cultured cells than unexposed ones.

Table (1): Effect of ultrasonication on the amylase and invertase activities of Arachis hypogaea cultured cells (mg of glucose $\mathrm{produced} / \mathrm{g}$ fresh weight/ hour)

\begin{tabular}{|c|c|c|}
\hline Enzymes & Cont. & Treated \\
\hline Amylase & $2.137 \pm 0.00$ & $\begin{array}{c}0.760 \pm 0.08 \\
* * *\end{array}$ \\
\hline Invertase & $0.124 \pm 0.03$ & $\begin{array}{c}0.088 \pm 0.02 \\
\mathrm{NS}\end{array}$ \\
\hline
\end{tabular}

Data are average of three replicates \pm SE. $\quad \mathrm{NS}=\mathrm{P}>0.05 \quad{ }^{* * *} \mathrm{HS}=\mathrm{P}>$ 0.001 


\section{STUDIES ON THE EFFECT OF ULTRASONIC}

WAVES ON:
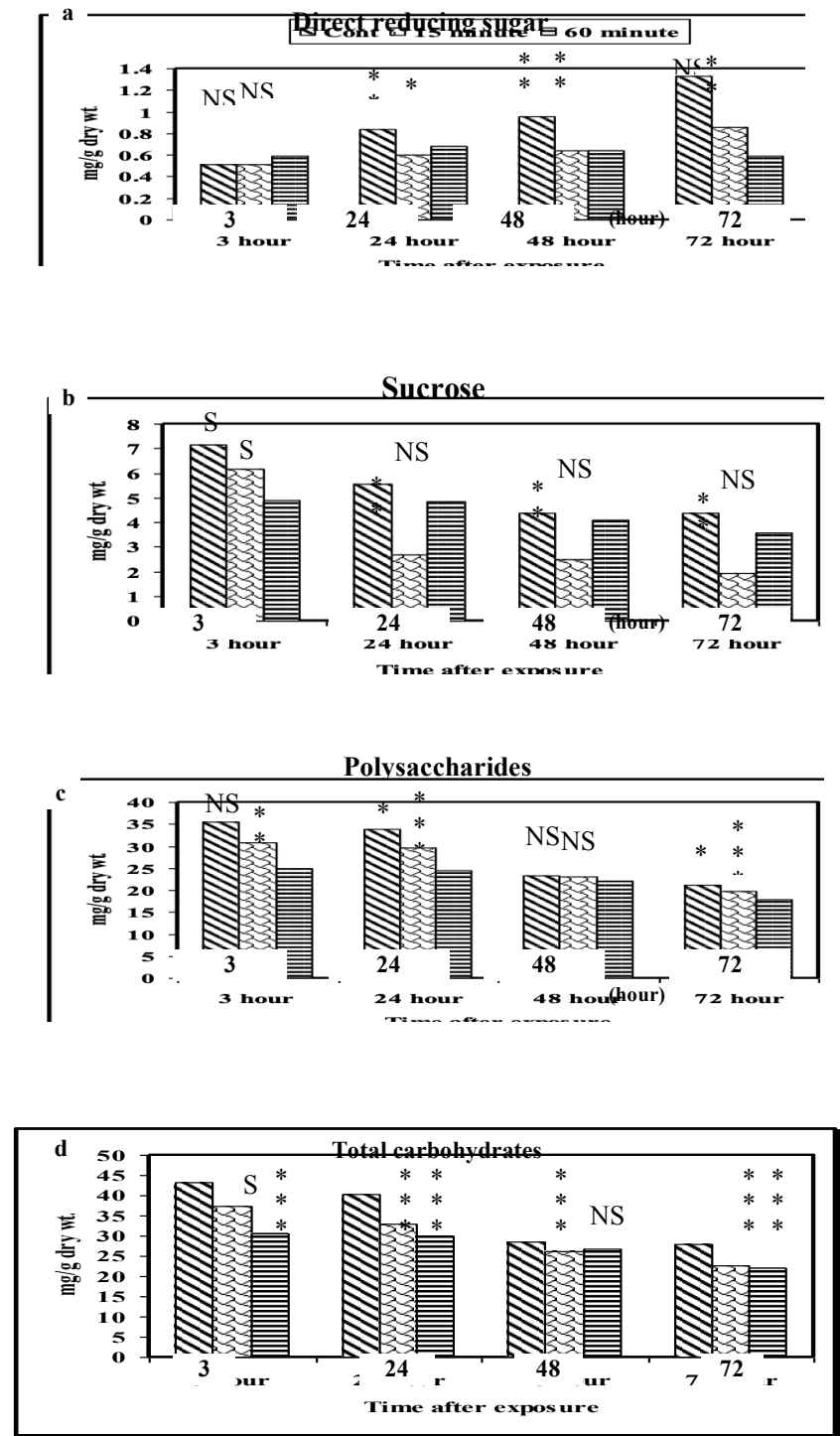

$\mathrm{NS}=\mathrm{P}>0.05 \quad \mathrm{~S}=\mathrm{P}<0.05 \quad \mathrm{HS}^{*}=\mathrm{P}>0.02 \quad \mathrm{HS}^{* *}=\mathrm{P}>0.01 \quad \mathrm{HS}^{* * *}=\mathrm{P}>0.001$

Figure (1): Effect of ultrasonication on sugar contents of peanut seedlings (mg/g dry weight 
Hegazy, H.S. et al.

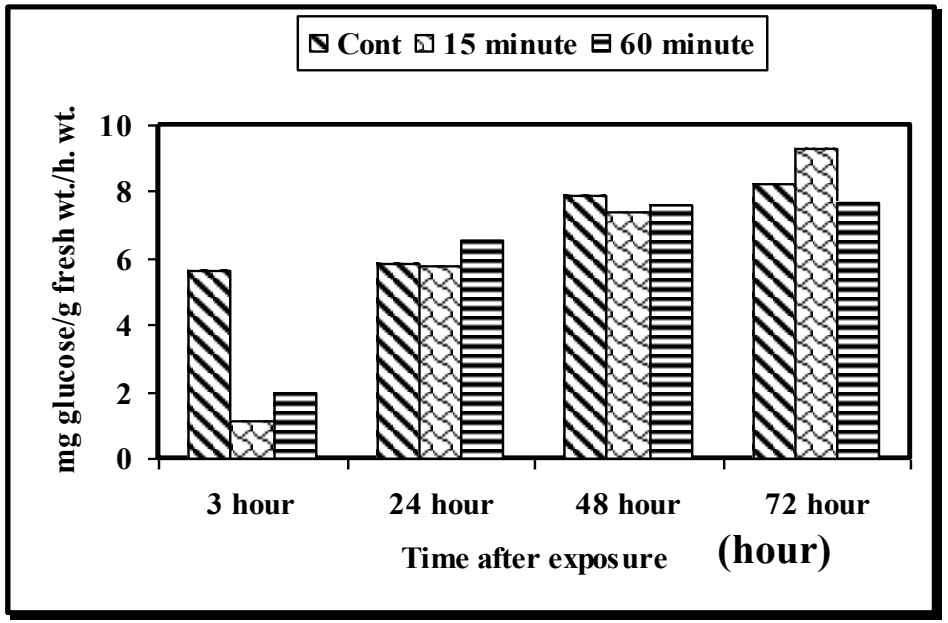

Figure (2): Effect of ultrasonication on amylase activity of peanut seedlings

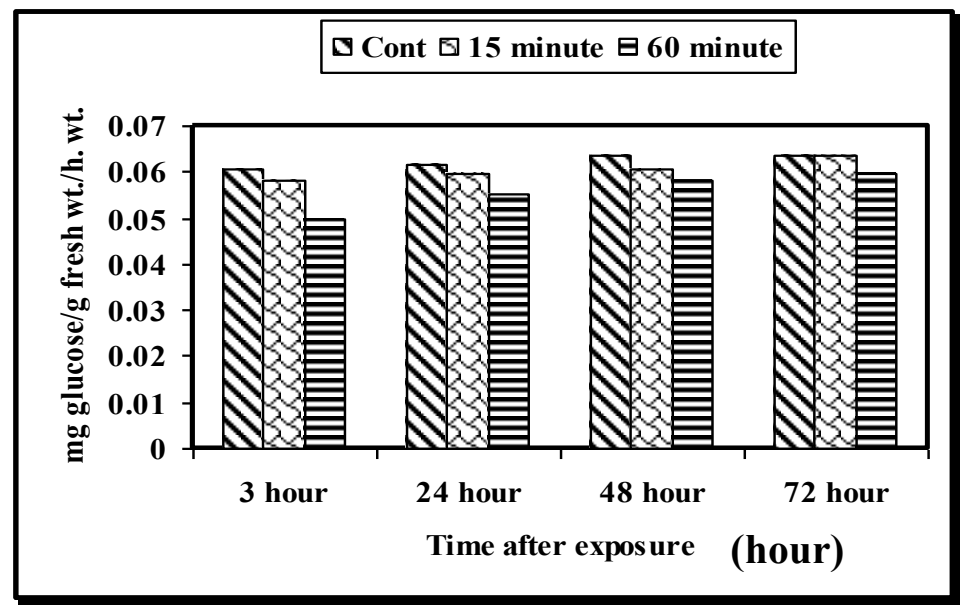

Figure (3): Effect of ultrasonication on invertase activity of peanut seedlings 


\section{STUDIES ON THE EFFECT OF ULTRASONIC WAVES ON:}

\section{DISCUSSION}

In the present work, it has been found that ultrasonication has obvious effect on the content of reducing sugar, sucrose, polysaccharides and total carbohydrates of the treated seedlings as compared with untreated. In this connection, ${ }^{(17)}$ stated that such reduction in the sugar fractions of ultrasonic treated cells might be predicted to the result of depolymarisation of starch and nucleoprotein.

Parallel to the amount of different sugar fractions in the treated and untreated seedlings, it was found that low amylase and invertase activities were corresponding, generally, to higher accumulation of the polysaccharides and sucrose respectively and vice verse. The obtained results were in agreement with $^{(18)}$, who stated that under stress condition increasing of the soluble sugar contents and breakdown of polysaccharides were assumed to be due to activation of amylolytic enzymes. Polysaccharides were considered to be broken-down during active germination whereas sucrose was known to represent the main mobile sugar to the embryo ${ }^{(19 \& 20)}$.

The obtained results showed also that, the activity of amylase increased sharply in the treated seedling after 24 hours than after 3 hours of ultrasonication, while it was gradually increased in case of untreated seedlings. But in long exposure, the increase of amylase activity was more obvious than that the shorter exposures (at 3, 24 and 48 hours after exposure) (Fig 2). In this connection ${ }^{(6)}$ stated that amylase activity of Vigna sinensis seedlings increased with ultrasonication and the increasing was more obvious in case of long exposure. In case of long exposure to ultrasonication (60 minutes), the reduction of amylase activity may be attributed to low gibberellin contents, which induced the synthesis of amylase. Yaldagard ${ }^{(21)}$ found that ultrasonication of dry barley seeds increased the activity of Alpha-amylase activity in the exposed seeds. In this respect, Davies ${ }^{(22)}$ stated that gibberellins, coming from the developing embryo in case of a germinating seed can stimulate aleurone cells to secrete several 
Hegazy, H.S. et al.

hydrolytic enzymes in particular, amylases. He added that these enzymes were responsible for the mobilization of stored endosperm reserves, which provide the growing seedling with a supply of fixed carbon and reduced nitrogen.

Invertase activity was inhibited with increasing time of exposure to ultrasonication from 15 to 60 minutes (Fig 3). The minimum invertase activity was obtained in the treated seedlings exposed to long exposure; comply with the low content of reducing sugars.

\section{REFERENCES}

(1) Chang, A.C. (2005): Study of ultrasonic wave treatments for accelerating the aging process in A rice alcoholic beverage. Food Chemistry, 92: 337-342.

(2) Toma, M.; Vinatoru, M.; Paniwnylk, L. and Mason, T.J. (2001): Investigation of the effects of ultrasound on vegetal tissues during solvent extraction. Ultrason. Snonch. 8: 137-142.

(3) Povey, M.J.W. and Mason, T.J. (1998): Ultrasound in food processing. International Thomson Publishing ITP. Pp. 115-125.

(4) Ravi Meher, E.L.; Reddy, K.C. and Krishnamurti, A.V.R.C. (1978): Effect of ultrasonic irradiation on the germination and growth of cashew seeds, National Seminar on Application of Acoustics and Ultrasonics, Baroda. India.

(5) Krishnamurthy, E.; Satyavati, A.V. and Vidyavati (1980): Effect of Ultrasonic Irradiation on Vigna sinensis (L.) (Papilionaceae), J. Pure Appl. Ultrason. 2 (3): 56-58.

(6) Reddy, K.J.M. and Vidyavati (1984): Effect of ultrasonics on Physio-Morphological variabilities in Dolichos biflorus L. Plant and Nature, 2 (2): 139-143.

(7) Rao, B.D. (1983): Effects of ultrasonics on Sirogonium phacosporum Skuja. J. Pure \& Appl. Ultrason. 5: 56-58.

(8) Reddy, K.J.M.; Sattaiah, G. and Vidyavati (1983): Effect of ultrasonic on seedling growth and activities of amylase and peroxidase in Vigna radiata Wilczek Ver. PS. 16, J. Pure Appl. Ultrason. 5: 70-72. 


\section{STUDIES ON THE EFFECT OF ULTRASONIC WAVES ON:}

(9) Murashig, T. and Skoog, F. (1962): A revised medium for rapid growth and bioassays with tobacco tissue cultures. Physiologia Plantarum 15: 473-497.

(10) Hegazy, H.S. (1987): Physiological and Ultrastructural Studies on Plants Infected with Agrobacterium tumefaciens, Pseudomonas solanacearum and Pseudomonas phaseolicola. Ph.D. Thesis, Sheffield. Univ. Sheffield, U.K.

(11) Younis, M.E. (1963): Studies of the Respiratory Metabolism in Strawberry Leaves. Ph.D., Thesis, Univ. of Cambridge.

(12) Nelson, N. (1944): Photometric adaptation of Somogi method for the determination of glucose. J. Biol. Chem., 153: 275-281.

(13) Naguib, M.J. (1964): Effect of sevin on the carbohydrates and nitrogen metabolism during the germination of cotton seeds. Ind. J. Exp. Biol., 2: 149-152.

(14) Naguib, M.I. (1963): Colorimetric estimation of polysaccharides. Zeit. Zucker, 16, 15.

(15) Bernfeld, P. (1955): Amylase, a \& b in the Methods in Enzymology. Vol. 1, Academic Press. Inc., New York, 149-150.

(16) Pressey, R. and Avants, J.K. (1980): Invertase in Oat seedling. Plant Physiol., 65: 136-140.

(17) Laland, S.; Overend, W.G. and Stacey, M. (1950): Some effects of the ultrasonic irradiation of DNA. Res. (London). 3: 386-394.

(18) Turner, N.C.; Begg, J.E. and Tonnet, M.X. (1978): Osmotic adjustment of sorghum and sunflower crops in response to water deficits and its influence on the water potential at which stomata close. Aust. J. Plant Physiol., 5: 597-608.

(19) Mayer, A.M. and Poljakoff-Mayber, A. (1982): The Germination of seeds. $3^{\text {rd }}$ ed. Pergamon Press, Oxford. England. R. Maxwell, Publisher.

(20) Still, M. and Steup, M. (1985): Starch and sucrose degradation, In: Encyclopedia of Plant Physiology, New Series, Vol. 18, 
Hegazy, H.S. et al.

Higher Plant Cell Respiration (R. Douce and D.A. Day, eds.) Springer Verlag, Berlin, 347.

(21) Yaldagard, M.; Mortazavi, S.A. and Tabatabaie, F. (2008): The effectiveness of ultrasound treatment on the germination stimulation of barley seed and its alpha-amylase activity. International Journal of Chemical and Biomolecular Engineering. 1: $55-58$.

(22) Davies, P.J. (1988): Hormone System and Metabolism, Page 2443 in Plant Hormones and Their Role in Plant Growth and Development. Klumer Academic Publishers. Dordrecht, Boston and London. 


\section{STUDIES ON THE EFFECT OF ULTRASONIC}

\section{WAVES ON:}

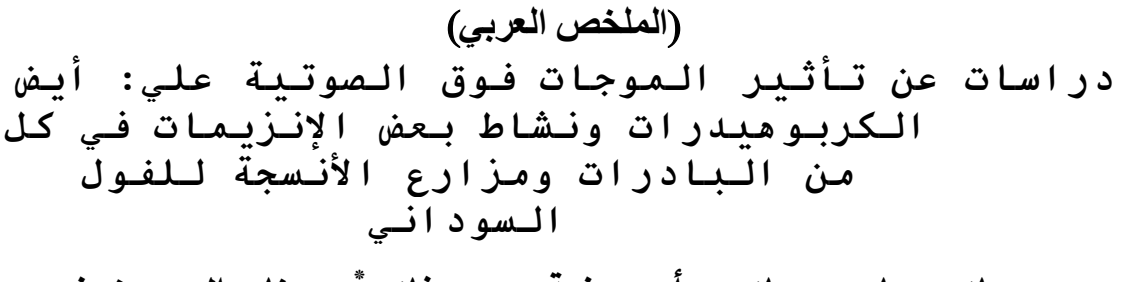

د. حجازي صادق حجازي ، أ.د صفية محمد غازي" ، حنان السيد ضيف

قسم النبات - كلية العلوم - جامعة الزقازيق

"قسم النبات - كلية العلوم - جامعة حلوان

إستهدف هذا البحث دراسة عن تأثير الموجات فوق الصوتية علي أيض الكربوهيدرات في بادرات الفول السوداني ونشـاط بعض الإنزيمات في كل من البادرات ومزارع الأنسجة

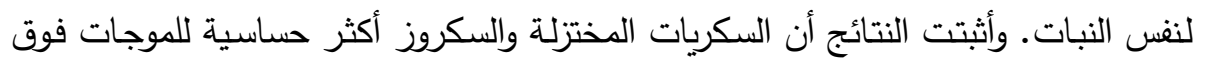
الصوتية عن الكربوهيدرات العديدة.

وأوضـحت النتـائج أيضـاً أن الاختزال في المحتـوي الكربوهيــراتي يـزداد بزيـادة فتـرة التعريض للموجات فوق الصوتية.

وأوضحت النتائج أيضاً أن نشاط إنزيم الأميليز في كل من البادرات ومزارع أنسجة الفول السوداني يزداد نتيجة التعريض للموجات فوق الصوتية بينما يحدث العكس في حالة إنزيم الإنفرتيز حيث يقل في كل من البـادرات ومـزارع الأنسـة نتيجة التعرض للموجـات فوق

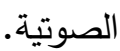

